Article

\title{
A Study on the Strategic Decision Making Used in the Revitalization of Fishing Village Tourism: Using A'WOT Analysis
}

\author{
Sangmin Lee ${ }^{1}$, Donghan Kim ${ }^{1}$, Sunwoo Park ${ }^{2, *} *$ and Wonseok Lee ${ }^{3}$ (i) \\ 1 Department of Convention and Hotel Management, Hannam University, Hannam-ro 70, Daedeok-gu, \\ Daejeon 34430, Korea; 1sm6516@hnu.kr (S.L.); eastkorea@hnu.kr (D.K.) \\ 2 Department of Leisure and Tourism, Kyonggi University, 24, Kyonggidae-ro 9-gil, Seodaemun-gu, \\ Seoul 03753, Korea \\ 3 Department of Tourism and Recreation, Kyonggi University, 24, Kyonggidae-ro 9-gil, Seodaemun-gu, \\ Seoul 03753, Korea; lws79877@gmail.com \\ * Correspondence: psw6363@gmail.com; Tel.: +82-10-9795-2326
}

Citation: Lee, S.; Kim, D.; Park, S.; Lee, W. A Study on the Strategic Decision Making Used in the Revitalization of Fishing Village Tourism: Using A'WOT Analysis. Sustainability 2021, 13, 7472.

https://doi.org/10.3390/su13137472

Academic Editor: Alan Fyall

Received: 30 April 2021

Accepted: 26 June 2021

Published: 5 July 2021

Publisher's Note: MDPI stays neutral with regard to jurisdictional claims in published maps and institutional affiliations.

Copyright: (c) 2021 by the authors. Licensee MDPI, Basel, Switzerland. This article is an open access article distributed under the terms and conditions of the Creative Commons Attribution (CC BY) license (https:/ / creativecommons.org/licenses/by/ $4.0 /)$.

\begin{abstract}
As society has developed, fishing villages that have relied solely on traditional fishing have found themselves on the verge of extinction. Therefore, efforts are being made to transform fishing villages into areas with various functions including recreation, tourism, and education. In this regard, the main purpose of this study is to analyze the relative importance and priorities of the multi-criteria decision-making (MCDM) process used in the revitalization of fishing village tourism. To this end, the A'WOT (AHP/SWOT) hybrid approach, developed in combination with the SWOT (Strengths, Weaknesses, Opportunities, Threats) analysis and the AHP (Analytic Hierarchy Process) method, was used to determine the significant factors. The results of the study demonstrated that the 'opportunities' and 'strengths' areas are relatively important when it comes to the priority of sustainable development. We also identified the high importance in terms of global weight of both 'Increased demand for leisure, rest and ecotourism' and 'Possession of natural resources of diverse and distinctive fishing villages by sea and region' as sustainable ways to revitalize fishing communities. This study demonstrates that with appropriate data and an applicable systematic process, the A'WOT approach can adequately show where intervention is most needed. The study shows that the application of tourism in the current context has the potential to approach the issue of fishing village tourism. Furthermore, this study is meaningful in that it quantifies the importance of fishing village tourism attributes by using a systematic approach, and it concludes with suggesting where the emphasis should be placed on policy and strategy.
\end{abstract}

Keywords: sustainable tourism; fishing village tourism; analytic hierarchy process (AHP), A'WOT; decision-making

\section{Introduction}

Fishing villages and oceans offer various resources and include excellent natural environments and unique cultures that can make such villages attractive spaces to meet the health, culture, and environmental needs of individuals [1,2]. However, as society has developed and the environment has changed, the catch, which is the major source of income in fishing villages, has declined significantly worldwide, making it difficult to address regional economic issues [3]. Fishing villages that have lost their ability to survive are gradually facing extinction, and there are real problems linked to the survival of fishing communities $[4,5]$. As a result, most coastal communities, which rely on fishing as a primary industry, are seeking various solutions to the environmental changes occurring as a result of the fishing crisis, integration with global markets, and climate change [6,7]. Rural areas, in a similar manner to fishing villages, are incorporating tourism in regional development 
in an attempt to solve the crisis of agriculture, which has itself lost the ability to support entire villages [8]. As a result, tourism has come to be recognized as a representative means of revitalizing rural areas $[9,10]$, and interest in rural tourism has recently steadily increased. Community-based tourism (CBT) in rural areas can improve the quality of life of residents in those areas [11,12]. It also increases respect for local cultures and maintains biodiversity [13-15]. In the same vein as the Sustainable Development Goals (SDGs), the United Nations' global goal is to preserve and promote local culture [16]. Just as rural areas have found vitality through tourism development, it is time for active discussion about introducing tourism as a means of revitalizing fishing villages. The links between fishing villages and tourism are actively being sought as part of a strategy to address the serious problems caused by the loss of income, which mainly comes from fishing, as well as the outflow of young people due to urbanization [17-19].

Korea is a peninsula, meaning three of its sides are surrounded by the sea, and it has suitable conditions for supporting various tourism activities along the coast. Since Korean fishing villages are richly unique in terms of scenery, culture, and fisheries resources, it is highly expected that regional development through tourism will regenerate the underdeveloped conditions and help the local economy. As a result, the government has implemented tourism policies in fishing villages based on government projects called the 3rd Basic Plan for Development of Fishing Villages \& Fishery Harbor 2020-2024 and the Fishing Village New-Deal 300 Project. Through these projects, the government has tried to improve tourism conditions in fishing villages. However, most of the fishing village tourism projects are planned to improve the basic lives of the local residents, so infrastructure continues to be created that is irrelevant to the purpose of the project, which is to emphasize the specialization of fishing villages. Therefore, to maximize the effectiveness of the development of fishing village tourism, it is necessary to both expand infrastructure and discover unique assets such as natural landscapes, cultural heritage sites, and local specialties. In addition, for fishing village tourism to serve as a sustainable means of revitalizing the region, it is essential to have systematic diagnosis and strategies to verify the environmental analysis and development direction [20]. In academic fields, prior studies on fishing village tourism have mainly focused on the characteristics and experiences of tourists, with a recent focus on topics such as residents' attitudes and environmental issues [21-23]; however, factors affecting the sustainable economic and community development of fishing villages and their application methods have scantly been discussed.

Therefore, we will establish a comprehensive scope encompassing aspects of various fields involving the economy, society, and environment for the sustainable development of fishing villages, and we will determine the ideal application of the direction of development. To this end, Multi-Criteria Decision Making (MCDM) will be used as a main method for selecting one optimal alternative based on various criteria for realistic problems [24-26]. Among them, we want to apply the A'WOT(AHP/SWOT) approach, a hierarchical decisionmaking approach which is mainly used in policymaking among MCDM techniques. It is an analysis approach that can identify priority policies based on the importance of expert opinions. The A'WOT approach is quite useful for establishing development strategies, as it can systematically identify the relative importance of factors derived in advanced approaches to improve the threshold of the strategic management tool, SWOT analysis (the acronym standing for Strengths, Weaknesses, Opportunities and Threats), and Analytic Hierarchy Process (AHP). Therefore, this research aims to identify the internal and external environmental factors in fishing village tourism in Korea and present objectives and specific strategies and development measures for revitalizing fishing village tourism in terms of sustainability. The biggest difference from the existing studies is that the existing studies take relatively macro and conceptual approaches to fishing village research, while this study practically demonstrates the level of the importance of the attributes of fishing village tourism through quantification, and it presents policies and strategies based on these findings. 


\section{Literature Review}

\subsection{Sustainable Fishing Village Tourism}

The United Nations presented the Sustainable Development Goals (SDGs) as a set of common goals for the international community to achieve together. These goals include elements of sound economic growth, social engagement, and sustainable development, and they emphasize central values such as harmony between humans and the environment, dignity, and equality. Among them, 'Decent Work and Economic Growth' (Goal 8), 'Responsible Consumption and Production' (Goal 12), and 'Preservation and sustainable use of ocean, sea and marine resources' (Goal 14) are directly related to tourism [27,28]. Accordingly, the World Tourism Organization (UNWTO) has applied the United Nations' Sustainable Development Goals (SDGs) to tourism to encourage sustainable tourism, fair tourism, green tourism, etc. [29]. According to the UNWTO, sustainable tourism is tourism that fully considers its own current, social, and environmental impacts, such as meeting the needs of visitors and communities, preserving natural cultural resources, and minimizing environmental damage [30].

It is important for the local communities to be involved in sustainable tourism. This is because the independent participation of residents in decision making related to the tourism development process plays a role in controlling the positive and negative impacts on the local community. To this end, CBT has been proposed to overcome the problems of largescale tourism development in which communities were excluded; as a sustainable tourism practice, it emphasizes community participation in the development process [31,32]. CBT refers to the development of tourism in a way that is harmless to the local culture, tradition, and daily life while satisfying the needs of the community, rather than emphasizing economic aspects alone.

In fishing villages, the subject of this study, fishery income has been gradually decreasing over the past few decades due to various factors, such as urbanization, climate change, pollution of coastal fisheries, overfishing, and reduced catch. Combined with accelerated fishing and the aging population, traditional fishing communities are on the verge of extinction $[4,5]$. As the majority of fishing communities which previously led this traditional lifestyle can no longer rely on fishing activities as their primary industry, there is a growing movement to seek additional income-generating measures other than fishing [33-35]. A fishing village also serves as a cultural heritage location [1] in that it has a unique natural environment and a rich fishing village traditional culture. In other words, fishing heritage can be used as a tourist product by combining nature with the traditional coastal culture [36]. Combining fishing and tourism in this context is an important way to ensure the viability of fishing communities and to promote fishing culture and enhance the sustainability of the traditional culture $[37,38]$.

The Korean government can also push for changes in the 3rd Basic Plan for Development of Fishing Villages \& Fishery Harbor 2020-2024 and the Fishing Village New-Deal 300 Project to revitalize fishing villages as attractive spaces [20,39].

However, these policies are not being systematically implemented with a long-term perspective. It is difficult to proceed in a continuous and collective manner due to the existence of individual business-oriented policies, and the top-down policies do not reflect regional characteristics because they rely on a uniform central government policy [39]. In addition, supporting policies are not implemented properly despite the abundance of natural and cultural resources in fishing villages, due to the aging population, exclusivity of fishing village residents, restrictions on fishing and marine resource utilization, and a general lack of understanding [40-42]. If the policies continue to be implemented in this way, support from the central and local governments is likely to become useless.

\subsection{Hierarchical Decision-Making Approach A'WOT}

One of the Multi-Criteria Decision-Making (MCDM) methods [43], A'WOT (SWOT/ AHP), which is a hierarchical decision-making technique, is a practical decision-making tool that combines SWOT and AHP to complement each of their shortcomings [44-46]. 
SWOT analysis has limitations, such as the fact that each factor cannot be quantitatively measured but combining it with AHP allows for a more purpose-appropriate strategy presentation $[47,48]$. The $\mathrm{A}^{\prime} \mathrm{WOT}$ analysis used in this work has the advantage of being able to simultaneously address both the qualitative characteristics of SWOT and the qualitative characteristics of AHP. The A'WOT analysis is largely conducted in three stages: the first step aims to identify the direction of strategy establishment or the factors that affect the decision making that researcher want to propose through their research. In the second step, the factors selected by SWOT analysis are analyzed using the AHP method. The analysis then proceeds by structuring a hierarchy and calculating the relative weights through pairwise comparison. As a final step, the weights of the four factors of SWOT produced during the second phase are multiplied by the weights of Strengths (S), Weaknesses (W), Opportunities $(\mathrm{O})$, and Threats $(\mathrm{T})$ to ultimately produce the final priority [49].

The existing studies that have applied A'WOT analysis have mainly used it to develop feasibility studies or competitiveness strategies to make efficient decisions, and they have not been limited to specific topics [50-52]. Kurtila (2000) was the first researcher to present an analysis of the final importance of factors by group using SWOT and AHP. Kurtila developed the scientific framework of A'WOT while focusing on the case of the Runni Center in Finland in a study on forest certification [47]. Since then, Pesonen, Kurtila, Kangas, Kajanus, and Heinonen have named the existing SWOT-AHP analysis A'WOT, and they have applied this research approach to various fields [49]. In 2004, local tourism experts expanded the scope of the analysis to tourism to promote rural tourism in the Kassel region of Germany and the Ylasavo region of Finland [53]. Wickramasinghe and Takano (2009) used A'WOT analysis to systematically establish strategies to boost the travel industry [54]. In addition, the $\mathrm{A}^{\prime} \mathrm{WOT}$ analysis approach is actively used as a research method to explore strategies for sustainable tourism. For example, Moharramnejad, Rahnamai, and Dorbeiki (2017) used the A'WOT approach to establish the best strategy for the long-term management of national parks [55], and Kişi (2019) used A'WOT analysis to derive strategic approaches to sustainable tourism development in Zonguldak, Turkey [56]. This range of tourism studies shows that the A'WOT analysis approach can be actively applied to determine the priorities of qualitative alternatives that are difficult to translate simply into quantitative figures, and that the approach can ultimately lead to more systematic and feasible decisions.

\section{Methods}

\subsection{Progress Step of $A^{\prime}$ WOT Approach}

The $A^{\prime}$ WOT approach can be divided into the following six-step procedure: In Step 1 , the goals are determined based on the SWOT framework, and a hierarchical model is organized. Next, step 2 produces pairwise comparisons of the criteria. This comparison is based on Saaty's 9-point scale for analytical efficiency [57,58]. In step 3, the local weights are evaluated with the AHP analysis method. Subsequently, step 4 confirms the reliability of the results within the consistency index (CI) and the consistency ratio (CR). In step 5 , if the $\mathrm{CR}$ value is generally less than 0.1 , the result is considered reliable; otherwise, the process of minimizing errors is conducted by repeating a pairwise comparison. This process is repeated until there is sufficient consistency. Finally, in step 6, the global weights of each alternative factor are aggregated and ranked.

\subsection{Model of Hierarchy Structure}

In this study, the SWOT factors were identified based on a review of previous studies on fishing village tourism [20,39,59-62]. Based on this, four factors have been determined within each SWOT group to enable a pairwise comparison of the AHP analysis. Table 1 below presents the SWOT-Matrix. 
Table 1. AHP factors and descriptions in SWOT-Matrix.

\begin{tabular}{|c|c|c|}
\hline SWOT Groups & & SWOT Factors \\
\hline \multirow{4}{*}{ Strengths $(S)$} & S1 & $\begin{array}{l}\text { Possession of natural resources of diverse and distinctive } \\
\text { fishing villages by sea and region }\end{array}$ \\
\hline & S2 & Geographical advantages of meeting the sea and land \\
\hline & S3 & $\begin{array}{l}\text { The development of a unique form of food, clothing, and } \\
\text { shelter cultures that have traditionally existed }\end{array}$ \\
\hline & S4 & Industrial characteristics that are easy to combine with tourism \\
\hline \multirow{4}{*}{$\begin{array}{l}\text { Weaknesses } \\
\qquad(\mathrm{W})\end{array}$} & W1 & $\begin{array}{l}\text { The outflow of fishing villages and the acceleration of the aging } \\
\text { population }\end{array}$ \\
\hline & W2 & The monotonous use of fishing village resources \\
\hline & W3 & The absence of a control tower for fishing village tourism \\
\hline & W4 & Tourists flock to certain seasons only \\
\hline \multirow{4}{*}{$\begin{array}{l}\text { Opportunities } \\
\qquad(\mathrm{O})\end{array}$} & O1 & $\begin{array}{l}\text { Promotion of fishing village development projects related to } \\
\text { SOC projects, such as fishing village and fishing port } \\
\text { regeneration projects }\end{array}$ \\
\hline & $\mathrm{O} 2$ & Increased demand for leisure, rest, and ecotourism \\
\hline & $\mathrm{O} 3$ & $\begin{array}{l}\text { Various income generation support policies for the influx of } \\
\text { people returning to the fishing village }\end{array}$ \\
\hline & $\mathrm{O} 4$ & Continuing interest in marine leisure tourism \\
\hline \multirow{4}{*}{ Treats $(\mathrm{T})$} & $\mathrm{T} 1$ & $\begin{array}{c}\text { Difficulty in establishing a new influx of population due to the } \\
\text { exclusive culture of fishing communities }\end{array}$ \\
\hline & $\mathrm{T} 2$ & Restrictive legal or institutional regulation provisions \\
\hline & T3 & $\begin{array}{l}\text { Increased damage caused by climate change and risk factors } \\
\text { related to marine environmental pollution }\end{array}$ \\
\hline & $\mathrm{T} 4$ & $\begin{array}{c}\text { Possibility of losing the original meaning of competitive } \\
\text { tourism development }\end{array}$ \\
\hline
\end{tabular}

In this study, based on SWOT analysis, a pairwise comparison was conducted on the strengths, weaknesses, threats, and opportunities in level 2, while in level 3, the relative importance of each factor was evaluated. The research model used in this study based on the SWOT-Matrix analysis is illustrated in Figure 1.

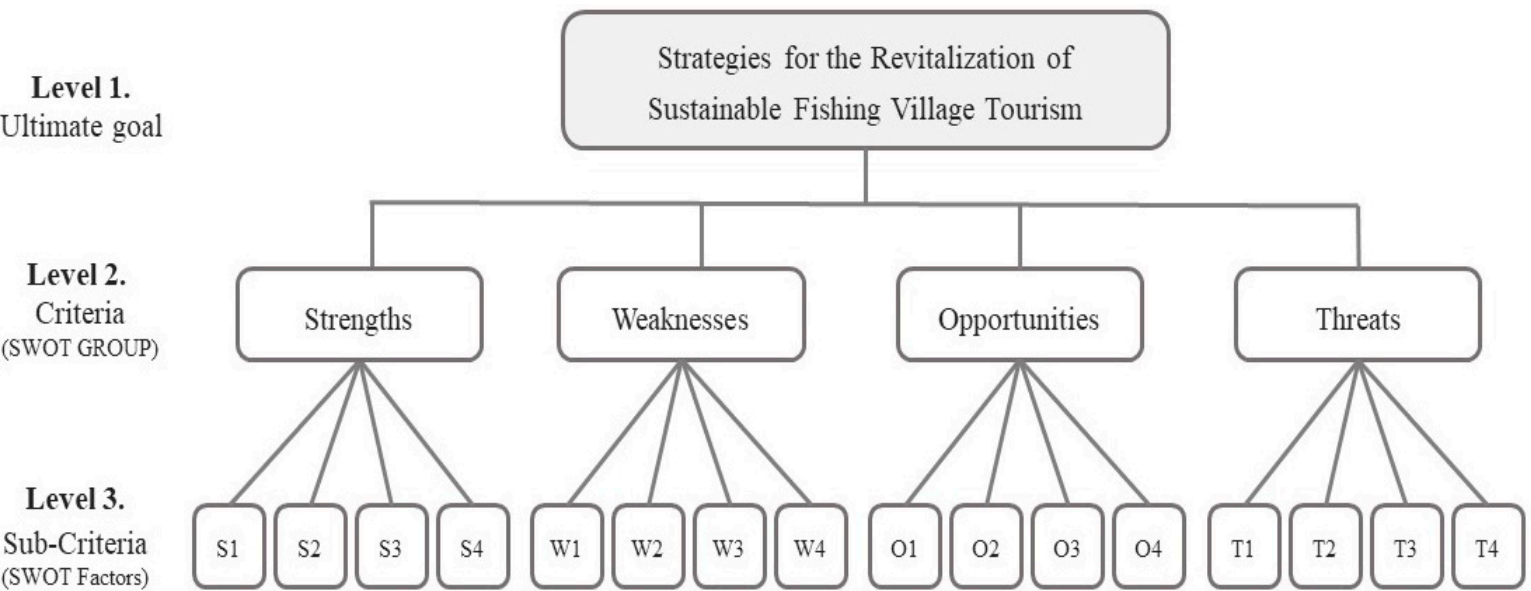

Figure 1. The hierarchical structure model. 


\subsection{Data Collection}

To secure the feasibility and reliability of the research, a survey was conducted by collecting a pool of experts with sufficient experience and knowledge in fishing village tourism. To gather opinions from various perspectives, a group of 12 academic experts (Professors), 13 policy experts (Government officials), and 13 working-level experts (persons working in professional tourism consulting firms above the manager level) was formed.

The purpose of the study was explained to each of the selected groups, and the questionnaires were distributed via email along with explanations of the $\mathrm{A}^{\prime}$ WOT integrated approach. The survey for AHP analysis was conducted from 7 April to 23 April. In total, 38 questionnaires were distributed, and 27 questionnaires with a consistency rate of 0.1 or less were ultimately analyzed as final subjects. In general, people tend to make inconsistent decisions, so decision-making should be used to judge consistency [57,58]. If the consistency index is generally less than 0.1 , it can be determined that reasonable consistency in the responses has been obtained [48,57].

\section{Results}

\subsection{Relative Importance of SWOT Groups}

Table 2 lists the results of the analysis of the relative importance among SWOT groups for the promotion of sustainable fishing village tourism: Level 2 factors for prioritization consisted of SWOT groups-strengths, weaknesses, opportunities, and threats-and the weights and priorities of the factors were derived through analysis. In the algebra matrix, the sum of priority vectors is one, and the priority vectors represent the relative importance between comparative factors [63]. The analysis showed that the order of importance was opportunities (0.328), strengths (0.318), threats (0.179), and weaknesses (0.174). This means that opportunities are approximately 1.88 times more important than weaknesses in policy prioritization $(0.328 / 0.174=1.88)$, so measures to capture opportunities as strategies to enhance them should be prioritized. In the evaluation of the SWOT groups, the high weight of opportunities and strengths can be interpreted as a positive evaluation of sustainable fishing village tourism, and 0.328 and 0.318 can be individually described as $32.8 \%$ and $31.8 \%$, respectively. The CR value is $0.024<0.1$, so mathematically, the condition is consistent.

Table 2. Relative importance of SWOT groups.

\begin{tabular}{ccc}
\hline SWOT Groups & Weights & SWOT Groups Rank \\
\hline Strengths (S) & 0.318 & 2 \\
\hline Weaknesses (W) & 0.174 & 4 \\
\hline Opportunities (O) & 0.328 & 3 \\
\hline Treats (T) & 0.179 & \\
\hline
\end{tabular}

\subsection{Relative Importance of SWOT Factors \\ 4.2.1. Local Weight}

Table 3 shows the results of examining the importance of internal factors within the SWOT group: "possession of natural resources of divergence and active fishing villages by sea and region" (0.410) was the most important factor in the strength category, followed by "industrial characteristics that are easy to combine with tourism" (0.249). In the case of weakness, "the monotonous use of fishing village resources" (0.304) was the most worrisome issue, followed by "the absence of a control tower for fishing village tourism" (0.267). In terms of opportunities related to fishing village tourism, "increased demand for leisure, rest, and ecotourism" (0.406) showed the highest importance, followed by "continuing interest in marine leisure tourism" (0.260). Regarding threats, "possibility of fading the original measuring of competitive tourism development" $(0.297)$ was the 
most threatening factor, followed by "increased damage by climate change and risk factors related to marine environmental conflict" (0.279).

Table 3. AHP local and global weights and ranking results.

\begin{tabular}{|c|c|c|c|c|c|c|}
\hline \multirow{2}{*}{ SWOT Groups } & \multirow{2}{*}{ Group Weights } & \multirow{2}{*}{ SWOT Factors } & \multicolumn{2}{|c|}{ Local } & \multicolumn{2}{|c|}{ Global } \\
\hline & & & Weights & Rank & Weights & Rank \\
\hline \multirow{4}{*}{ Strengths (S) } & \multirow{4}{*}{0.318} & $\begin{array}{l}\text { Possession of natural resources of diverse and } \\
\text { distinctive fishing villages by sea and region }\end{array}$ & 0.410 & 1 & 0.130 & 2 \\
\hline & & $\begin{array}{l}\text { Geographical advantages of meeting the sea } \\
\text { and land }\end{array}$ & 0.156 & 4 & 0.050 & 10 \\
\hline & & $\begin{array}{l}\text { The development of a unique form of food, } \\
\text { clothing, and shelter cultures that have } \\
\text { traditionally existed }\end{array}$ & 0.185 & 3 & 0.059 & 6 \\
\hline & & $\begin{array}{l}\text { Industrial characteristics that are easy to } \\
\text { combine with tourism }\end{array}$ & 0.249 & 2 & 0.079 & 4 \\
\hline \multirow{4}{*}{ Weaknesses (W) } & \multirow{4}{*}{0.174} & $\begin{array}{l}\text { The outflow of fishing villages and the } \\
\text { acceleration of the aging population }\end{array}$ & 0.220 & 3 & 0.038 & 14 \\
\hline & & $\begin{array}{c}\text { The monotonous use of fishing village } \\
\text { resources }\end{array}$ & 0.304 & 1 & 0.053 & 8 \\
\hline & & $\begin{array}{c}\text { The absence of a control tower for fishing } \\
\text { village tourism }\end{array}$ & 0.267 & 2 & 0.047 & 12 \\
\hline & & Tourists flock to certain seasons only & 0.210 & 4 & 0.037 & 15 \\
\hline \multirow{4}{*}{$\begin{array}{l}\text { Opportunities } \\
\text { (O) }\end{array}$} & \multirow{4}{*}{0.328} & $\begin{array}{c}\text { Promotion of fishing village development } \\
\text { projects related to SOC projects, such as } \\
\text { fishing village and fishing port regeneration } \\
\text { projects }\end{array}$ & 0.183 & 3 & 0.060 & 5 \\
\hline & & $\begin{array}{l}\text { Increased demand for leisure, rest, and } \\
\text { ecotourism }\end{array}$ & 0.406 & 1 & 0.133 & 1 \\
\hline & & $\begin{array}{l}\text { Various income generation support policies } \\
\text { for the influx of people returning to fishing } \\
\text { villages }\end{array}$ & 0.151 & 4 & 0.049 & 11 \\
\hline & & Continuing interest in marine leisure tourism & 0.260 & 2 & 0.085 & 3 \\
\hline \multirow{4}{*}{ Treats $(\mathrm{T})$} & \multirow{4}{*}{0.179} & $\begin{array}{l}\text { Difficulty in establishing a new influx of } \\
\text { population due to the exclusive culture of } \\
\text { fishing communities }\end{array}$ & 0.184 & 4 & 0.033 & 16 \\
\hline & & $\begin{array}{l}\text { Restrictive legal or institutional regulation } \\
\text { provisions }\end{array}$ & 0.239 & 3 & 0.043 & 13 \\
\hline & & $\begin{array}{l}\text { Increased damage caused by climate change } \\
\text { and risk factors related to marine } \\
\text { environmental pollution }\end{array}$ & 0.279 & 2 & 0.050 & 9 \\
\hline & & $\begin{array}{l}\text { Possibility of losing the original meaning of } \\
\text { competitive tourism development }\end{array}$ & 0.297 & 1 & 0.053 & 7 \\
\hline
\end{tabular}

\subsubsection{Global Weight}

Finally, global weights were obtained by aggregating weights obtained at a hierarchical level to determine the weights of various factors to be considered in sustainable fishing village tourism. Global weights can be obtained by multiplying SWOT group priorities (level 2) and importance (3) values within the group. The analysis results of the overall importance are listed in Table 3. The comprehensive analysis showed that the opportunity factor O2 ("increased demand for leisure, rest, and ecotourism" (0.133)) had the highest importance, followed by strength factor S1 ("possession of natural resources of divergence and active fishing villages by sea and region" (0.130)) and opportunity factor $\mathrm{O} 4$ 
("continuing interest in marine leisure tourism" (0.085)). The overall relative importance of each of the strengths and opportunity factors ranked higher than those of the other groups, while the importance of the weakness groups was relatively the lowest.

\section{Discussion and Conclusions}

It is important to analyze the relative importance of the various factors surrounding fishing villages to effectively support projects involving such villages. Therefore, this study examined the important factors of fishing village tourism through a scientific and objective analysis aiming toward the rational implementation of fishing village tourism policies from a sustainable tourism perspective. Accordingly, significant factors of fishing village tourism were identified using the A'WOT approach specialized in hierarchical decision-making approaches, which is expected to provide important implications for fishing village tourism policies.

For this analysis, a literature review was conducted to identify the factors of fishing village tourism, then SWOT factors related to the internal and external environments of fishing village tourism were determined based on this review. In addition, related experts were asked for their opinions on the priorities of the derived factors, and their importance was identified using the pairwise-comparison method. Through this process, the importance of each SWOT group's factor could be determined along with the priority of the entire group.

The results of this study show that, of the four SWOT factors, it is relatively important to strengthen the opportunity factors (0.328) and strength factors $(0.318)$ in the priorities of the policy. The results showing the high importance of these opportunities and strength factors indicate that they are related to changes in the role of fishing villages, increased interest in community-based tourism and ecotourism, and positive prospects for changes in leisure culture demand. In addition, O3 ("increased demand for leisure, rest, and ecotourism" (0.133)), S1 ("possession of natural resources of diverse and distinctive fishing villages by sea and region" (0.130)), and $\mathrm{O} 4$ ("continuing interest in marine leisure" and the sequence of comment projects related to SOC projects, such as fishing village and fishing port regeneration projects (0.060)) appear to be among the significant top five factors that represent the highest importance of the 16 SWOT factors in developing a detailed strategy.

In addition, as opportunities and strength factors rank high in the overall ranking, experts who participated in the survey think that these factors should be considered first when converging and utilizing tourism as a sustainable way to revitalize fishing villages. In other words, it will be more important than anything else to actively utilize the strengths of fishing villages. To this end, various efforts and organizational support will be needed to develop fishing village tourism as a new complex tourism area beyond the traditional role of existing fishing villages.

This study is meaningful in that it provides detailed strategies for fishing villages, which overlooked by previous research more focusing on conceptual aspects $[1,19,61-63]$. In other words, this study is differentiated from existing research in that effective and realistic strategies have been derived by the systematic process. That is, AWOT help systematically and scientifically identify the rankings of various attributes to promote effective fishing village tourism policies and thus provide meaningful evidence for more successful tourism policies.

\section{Implication and Limitation}

This study can provide rich practical implications in that the results of this study can be used to establish policies or effective strategies related to the revitalization of fishing villages. First, the results showing that active development strategies using strengths and opportunity factors, along with high priority for O3 ("increased demand for leisure, rest, and ecotourism") and S1 ("possession of natural resources of diverse and distinctive fishing villages by sea and region"), seem to reflect a recent interest in alternative tourism and green tourism trends. Fishing resources and ecological environments are important factors 
in the nature of fishing communities, because the sustainability of fishing communities can be determined by the ecological environment of the sea. As the results of this study show that the use of natural resources is a high priority, fishing village tourism needs to be approached under the premise of maintaining the ecological environment of fishing villages. The increased interest in fishing village tourism could potentially lead to destruction of the natural environment of the region if numerous tourists visit small fishing villages in the short term, which would ultimately decrease the number of tourists visiting fishing villages for ecotourism.

Therefore, for the sustainability of fishing villages, measures to preserve and utilize unique fishing village resources should be established. These measures need to be accompanied by environmental education for tourists to enhance environmental awareness. This will not only help the long-term sustainability of ecotourism, which would suggest that the natural environment is a large aspect of ecotourism, but it will also help maintain the life of residents and minimize noise as well as damage to nature and living spaces. In addition, fishing villages have unique tourism resources compared to other areas. Therefore, it is important to discover resources that can enhance the value of the local ecology, culture, and history.

There would still be some emphasis on establishing infrastructure, just not a sole emphasis. Hence, for resources in fishing villages to function properly, residents with a rich understanding of the resources should also be encouraged to participate in tourism development. It will be necessary to create small-scale development programs in which residents and local communities can participate and to develop programs that allow tourists to blend in with residents and experience unique fishing village cultures. In particular, the experience of fishing villages' lifestyles and traditional fishing methods could be a great intangible asset of fishing villages, which could facilitate exchanges between residents and tourists. Therefore, it is necessary to encourage fishing village residents to actively participate in tourism projects and to provide them with education and consulting to raise awareness of the potential added value and potential of tourism projects. Furthermore, residents who participate in fishing village tourism projects should continue to develop contents based on the unique living customs and historical cultures of fishing villages, rather than providing tourists with simple opportunities to harvest or catch fishery products. Developing original tourism products using unique resources by utilizing identity and individuality for each type of fishing village will help preserve and excavate fishing heritage and contribute to social and cultural revitalization through factors such as cultural succession and development.

However, despite these results and implications, this study has several limitations: First, the characteristics of fishing village tourism could be divided into regional and cultural divisions, but this study would not clearly reflect this. Therefore, future studies should aim to further segment the types of fishing villages to establish more specific development strategies. In addition, this study simply considered factors directly related to the promotion of fishing village tourism. Furthermore, priorities or importance may vary depending on the nature of the expert group. Therefore, future studies can obtain more in-depth results by conducting cross-group comparisons together by dividing groups of experts by type. However, future research needs to be conducted in consideration of various factors that can be linked to fishing village tourism. Despite these limitations, this study is expected to be significant in that it contributes to establishing tourism policies and strategies to sustainably revitalize fishing villages.

Author Contributions: S.P. writing original draft; D.K. resources; S.L. writing review and editing; and W.L. supervision. All authors have read and agreed to the published version of the manuscript.

Funding: This work was supported by the Ministry of Education of the Republic of Korea and the National Research Foundation of Korea (NRF-2020S1A5A8046228).

Institutional Review Board Statement: Not applicable. 
Informed Consent Statement: Not applicable.

Data Availability Statement: Not applicable.

Conflicts of Interest: The authors declare no conflict of interest.

\section{References}

1. De Madariaga, C.J.; del Hoyo, J.J.G. Enhancing of the cultural fishing heritage and the development of tourism: A case study in Isla Cristina (Spain). Ocean. Coast. Manag. 2019, 168,1-11. [CrossRef]

2. Wang, L.; Zhang, H. The Impact of Marine Tourism Resources Development on Sustainable Development of Marine Economy. J. Coast. Res. 2019, 94, 589-592. [CrossRef]

3. Guardian Media Group. Fish Stocks Continuing to Fall as Oceans Warm, Study Finds. 2019. Available online: https://www. theguardian.com/environment/2019/feb/28/fish-stocks-continuing-to-fall-as-oceans-warm-study-finds (accessed on 30 April 2020).

4. Allison, E.H.; Adger, W.N.; Badjeck, M.C.; Brown, K.; Conway, D.; Dulvy, N.K.; Reynolds, J.D. Effects of Climate Change on the Sustainability of Capture and Enhancement Fisheries Important to the Poor: Analysis of the Vulnerability and Adaptability of Fisherfolk Living in Poverty; Technical Report; Department for International Development: London, UK, September 2005.

5. McClanahan, T.; Allison, E.; Cinner, J. Managing fisheries for human and food security. Fish Fish. 2013, 16, 78-103. [CrossRef]

6. Perry, R.I.; Ommer, E.R.; Barange, M.; Jentoft, S.; Neis, B.; Sumaila, U.R. Marine social-ecological responses to environmental change and the impacts of globalization. Fish Fish. 2011, 12, 427-450. [CrossRef]

7. Defeo, O.; Castrejón, M.; Ortega, L.; Kuhn, A.M.; Gutiérrez, N.L.; Castilla, J.C. Impacts of climate variability on Latin American small-scale fisheries. Ecol. Soc. 2013, 18, 30. [CrossRef]

8. Gao, J.; Wu, B. Revitalizing traditional villages through rural tourism: A case study of Yuanjia Village, Shaanxi Province, China. Tour. Manag. 2017, 63, 223-233. [CrossRef]

9. Hwang, D.; Stewart, W.P.; Ko, D.-W. Community Behavior and Sustainable Rural Tourism Development. J. Travel Res. 2011, 51, 328-341. [CrossRef]

10. Huang, W.-J.; Beeco, J.A.; Hallo, J.C.; Norman, W.C. Bundling attractions for rural tourism development. J. Sustain. Tour. 2016, 24, 1387-1402. [CrossRef]

11. Gurung, D.B.; Seeland, K. Ecotourism in Bhutan: Extending its benefits to rural communities. Ann. Tour. Res. 2008, 35, 489-508. [CrossRef]

12. Sebastian, L.M.; Rajagopalan, P. Socio-cultural transformations through tourism: A comparison of residents' perspectives at two destinations in Kerala, India. J. Tour. Cult. Chang. 2009, 7, 5-21. [CrossRef]

13. Lee, T.H.; Jan, F.-H.; Yang, C.-C. Conceptualizing and measuring environmentally responsible behaviors from the perspective of community-based tourists. Tour. Manag. 2013, 36, 454-468. [CrossRef]

14. Dodds, R.; Ali, A.; Galaski, K. Mobilizing knowledge: Determining key elements for success and pitfalls in developing community-based tourism. Curr. Issues Tour. 2016, 21, 1547-1568. [CrossRef]

15. Tang, R.; Kang, S.; Lee, W.S.; Park, S. Influence of residents' perceptions of tourism development on their affective commitment, altruistic behavior, and civic virtue for community. Int. J. Tour. Res. 2021. [CrossRef]

16. Lee, T.H.; Jan, F.-H. Can community-based tourism contribute to sustainable development? Evidence from residents' perceptions of the sustainability. Tour. Manag. 2019, 70, 368-380. [CrossRef]

17. Chen, C.-L.; Chang, Y.-C. A transition beyond traditional fisheries: Taiwan's experience with developing fishing tourism. Mar. Policy 2017, 79, 84-91. [CrossRef]

18. Rogelja, N.; Spreizer, A.J. Fish on the Move. In MARE Publication Series; Springer Science and Business Media LLC: Berlin/Heidelberg, Germany, 2017; Volume 11.

19. González, R.C.L.; Piñeiro Antelo, M.D.L.Á. Fishing Tourism as an Opportunity for Sustainable Rural Development-The Case of Galicia, Spain. Land 2020, 9, 437. [CrossRef]

20. Ministry of Oceans and Fisheries. 2019 the 3rd Basic Plan for Development of Maritime Fisheries Industry (2021-2030). Ministry of Oceans and Fisheries. Available online: https:/ / www.mof.go.kr/synap/view.do?fn=MOF_ARTICLE_28390_2019123116f5a7 76100590\&fd=202104 (accessed on 2 July 2021).

21. Lacher, R.G.; Oh, C.O.; Jodice, L.W.; Norman, W.C. The role of heritage and cultural elements in coastal tourism destination preferences: A choice modeling-based analysis. J. Travel Res. 2013, 52, 534-546. [CrossRef]

22. Porter, B.A.; Orams, M.B.; Lück, M. Surf-riding tourism in coastal fishing communities: A comparative case study of two projects from the Philippines. Ocean Coast. Manag. 2015, 116, 169-176. [CrossRef]

23. Jodice, L.W.; Norman, W.C. Comparing importance and confidence for production and source attributes of seafood among residents and tourists in South Carolina and Florida coastal communities. Appetite 2020, 146, 104510. [CrossRef]

24. Zavadskas, E.K.; Turskis, Z. Multiple Criteria Decision Making (Mcdm) Methods in Economics: An Overview/Daugiatiksliai Sprendimu Prièmimo Metodai Ekonomikoje: Apžvalga. Technol. Econ. Dev. Econ. 2011, 17, 397-427. [CrossRef]

25. Zavadskas, E.K.; Govindan, K.; Antucheviciene, J.; Turskis, Z. Hybrid multiple criteria decision-making methods: A review of applications for sustainability issues. Econ. Res. Ekon. Istraživanja 2016, 29, 857-887. [CrossRef] 
26. Turskis, Z.; Goranin, N.; Nurusheva, A.; Boranbayev, S. Information security risk assessment in critical infrastructure: A hybrid MCDM approach. Informatica 2019, 30, 187-211. [CrossRef]

27. Glaesser, D.; Kester, J.; Paulose, H.; Alizadeh, A.; Valentin, B. Global travel patterns: An overview. J. Travel Med. 2017, 24, 1-5. [CrossRef]

28. Jones, P.; Hillier, D.; Comfort, D. The Sustainable Development Goals and the Tourism and Hospitality Industry. Athens J. Tour. 2017, 4, 7-18. [CrossRef]

29. Nguyen, T.Q.T.; Young, T.; Johnson, P.; Wearing, S. Conceptualising networks in sustainable tourism development. Tour. Manag. Perspect. 2019, 32, 100575. [CrossRef]

30. Hall, C.M. Constructing sustainable tourism development: The 2030 agenda and the managerial ecology of sustainable tourism. J. Sustain. Tour. 2019, 27, 1044-1060. [CrossRef]

31. Friedmann, J. Empowerment: The Politics of Alternative Development; Blackwell: Columbus, OH, USA, 1992.

32. Mitchell, R.E.; Reid, D.G. Community integration: Island tourism in Peru. Ann. Tour. Res. 2001, 28, 113-139. [CrossRef]

33. Brugère, C.; Holvoet, K.; Allison, E.H. Livelihood Diversification in Coastal and Inland Fishing Communities: Mis-conceptions, Evidence, and Implications for Fisheries Management; Working paper for Sustainable Fisheries Livelihoods Programme (SFLP): Rome, Italy, June 2008.

34. Budzich-Tabor, U. Area-based Local Development-A New Opportunity for European Fisheries Areas. In MARE Publication Series; Springer Science and Business Media LLC: Berlin/Heidelberg, Germany, 2014; pp. 183-197.

35. Prosperi, P.; Kirwan, J.; Maye, D.; Bartolini, F.; Vergamini, D.; Brunori, G. Adaptation strategies of small-scale fisheries within changing market and regulatory conditions in the EU. Mar. Policy 2019, 100, 316-323. [CrossRef]

36. Park, S.; Chung, N.; Lee, W. Preserving the Culture of Jeju Haenyeo (Women Divers) as a Sustainable Tourism Resource. Sustainability 2020, 12, 10564. [CrossRef]

37. Howard, P.; Pinder, D. Cultural heritage and sustainability in the coastal zone: Experiences in south west England. J. Cult. Herit. 2003, 4, 57-68. [CrossRef]

38. Kaltenborn, B.P.; Linnell, J.D.C.; Baggethun, E.G.; Lindhjem, H.; Thomassen, J.; Chan, K.M. Ecosystem Services and Cultural Values as Building Blocks for 'The Good life'. A Case Study in the Community of Røst, Lofoten Islands, Norway. Ecol. Econ. 2017, 140, 166-176. [CrossRef]

39. Ministry of Oceans and Fisheries. Fishing Village New-deal 300 Project. Ministry of Oceans and Fisheries. Available online: https: / / www.mof.go.kr/en/page.do?menuIdx=1487 (accessed on 2 July 2021).

40. KBS NEWS. [Exploration K] Fishing Village New Deal (1) Stigma in Problem Business ... Where's the Rosy View? Available online: https: / / news.kbs.co.kr/news/view.do?ncd=5081537 (accessed on 30 April 2020).

41. Agrinet. Fishing Village Tourism Diagnosis (3) Development Direction and Tasks. Available online: http://www.agrinet.co.kr/ news / articleView.html?idxno=67397 (accessed on 30 April 2020).

42. The Agriculture, Fisheries, Livestock News. The Shadow of Extinction on the Fishing Village. Available online: http://www. aflnews.co.kr/news/articleView.html?idxno=208740 (accessed on 30 April 2020).

43. Zavadskas, E.; Turskis, Z.; Tamosaitiene, J. Selection of construction enterprises management strategy based on the SWOT and multi-criteria analysis. Arch. Civ. Mech. Eng. 2011, 11, 1063-1082. [CrossRef]

44. Kangas, J.; Kangas, A.; Leskinen, P.; Pykäläinen, J. MCDM methods in strategic planning of forestry on state-owned lands in Finland: Applications and experiences. J. Multi-Criteria Decis. Anal. 2001, 10, 257-271. [CrossRef]

45. Canto-Perello, J.; Curiel-Esparza, J.; Calvo, V. Strategic decision support system for utility tunnel's planning applying A'WOT method. Tunn. Undergr. Space Technol. 2016, 55, 146-152. [CrossRef]

46. Bottero, M.; D'Alpaos, C.; Marello, A. An Application of the A'WOT Analysis for the Management of Cultural Heritage Assets: The Case of the Historical Farmhouses in the Aglié Castle (Turin). Sustainability 2020, 12, 1071. [CrossRef]

47. Kurttila, M.; Pesonen, M.; Kangas, J.; Kajanus, M. Utilizing the analytic hierarchy process (AHP) in SWOT analysis-a hybrid method and its application to a forest-certification case. For. Policy Econ. 2000, 1, 41-52. [CrossRef]

48. Saaty, T.L.; Vargas, L.G. How to make a decision. In Models, Methods, Concepts E Applications of the Analytic Hierarchy Process; Springer: Boston, MA, USA, 2001; pp. 1-25.

49. Pesonen, M.; Kurttila, M.; Kangas, J.; Kajanus, M.; Heinonen, P. Assessing the priorities using A'WOT among resource management strategies at the Finnish Forest and Park Service. For. Sci. 2001, 47, 534-541.

50. Akbulak, C.; Cengiz, T. Determining ecotourism strategies using A'WOT hybrid method: Case study of Troia Historical National Park, Çanakkale, Turkey. Int. J. Sustain. Dev. World Ecol. 2013, 21, 380-388. [CrossRef]

51. Tavana, M.; Zareinejad, M.; Di Caprio, D.; Kaviani, M.A. An integrated intuitionistic fuzzy AHP and SWOT method for outsourcing reverse logistics. Appl. Soft Comput. 2016, 40, 544-557. [CrossRef]

52. Abdel-Basset, M.; Mohamed, M.; Smarandache, F. An Extension of Neutrosophic AHP-SWOT Analysis for Strategic Planning and Decision-Making. Symmetry 2018, 10, 116. [CrossRef]

53. Kajanus, M.; Kangas, J.; Kurttila, M. The use of value focused thinking and the A'WOT hybrid method in tourism management. Tour. Manag. 2004, 25, 499-506. [CrossRef] 
54. Wickramasinghe, V.S.K.; Takano, S.E. Application of combined SWOT and analytic hierarchy process (AHP) for tourism revival strategic marketing planning. In Proceedings of the Eastern Asia Society for Transportation Studies Volume 7 (The 8th International Conference of Eastern Asia Society for Transportation Studies, 2009), Eastern Asia Society for Transportation Studies, Surabaya, Indonesia, 16-19 November 2009; p. 189.

55. Moharramnejad, N.; Rahnamai, M.T.; Dorbeiki, M. Application of a'wot method in strategic management of sus-tainable tourism in a national park. Environ. Eng. Manag. J. 2017, 16, 471-480.

56. Kişi, N. A Strategic Approach to Sustainable Tourism Development Using the A'WOT Hybrid Method: A Case Study of Zonguldak, Turkey. Sustainability 2019, 11, 964. [CrossRef]

57. Saaty, T.L. Group Decision Making and the AHP. In The Analytic Hierarchy Process; Springer: Berlin/Heidelberg, Germany, 1989; pp. 59-67.

58. Saaty, T.; Vargas, L. Estimating technological coefficients by the analytic hierarchy process. Socio-Econ. Plan. Sci. 1979, 13, 333-336. [CrossRef]

59. Cheong, S.-M. Privatizing tendencies: Fishing communities and tourism in Korea. Mar. Policy 2003, 27, 23-29. [CrossRef]

60. Lee, Y.J.; Song, Y.M.; Lee, K.P. A Typology of Experience Program of Fishing Village Tourism in Gangneung-An Application of Model of the Four Realms of an Experience by Pine \& Gilmore. J. Fish. Mar. Sci. Educ. 2011, 23, 695-708.

61. Lee, S.-G.; Midani, A.R. Fishery self-governance in fishing communities of South Korea. Mar. Policy 2015, 53, 27-32. [CrossRef]

62. Wang, J.-Y.; Ai, W.-Z.; Hu, B.-H. The SWOT Analysis and Countermeasures Research of Zhoushan Leisure Fishery under the New Situation. DEStech Trans. Soc. Sci. Educ. Hum. Sci. 2018, 75-79. [CrossRef]

63. Lee, S.; Walsh, P. SWOT and AHP hybrid model for sport marketing outsourcing using a case of intercollegiate sport. Sport Manag. Rev. 2011, 14, 361-369. [CrossRef] 